\title{
The Social Function of Swearing in a Miraa Market Environment
}

Mukuni $\mathrm{DM}^{1^{*}}$, Ireri $\mathrm{AM}^{2}$, Nthiga $\mathrm{PM}^{1}$ and Owili FA ${ }^{1}$

${ }^{1}$ Department of English and Linguistics, Kenyatta University, Nairobi, Kenya

${ }^{2}$ Department of Educational Psychology, Kenyatta University, Nairobi, Kenya

*Corresponding author: Mukuni DM, Department of English and Linguistics, Kenyatta University, 43844-00100, Nairobi, Kenya, Tel: +254208710901; E-mail: mukunid7@gmail.com

Received date: April 13, 2016; Accepted date: May 16, 2016; Published date: May 20, 2016

Copyright: ( 2016 Mukuni DM, et al. This is an open-access article distributed under the terms of the Creative Commons Attribution License, which permits unrestricted use, distribution, and reproduction in any medium, provided the original author and source are credited.

\begin{abstract}
The study aimed at evaluating the social motivations behind the use of swearwords in the language of miraa traders. The study was carried out in Kĩritirĩ open-air miraa (khat) market in Mbeere South sub-county within Embu County. Twelve negotiations involving both male and female traders were recorded and subsequently analyzed. The analysis indicates that swearing is an intricate social practice that is highly gendered, and which is used to not only socialize but also to achieve highly precious transactional goals in the miraa market. Significantly, swearing is a way in which the Miraa traders establish both their social and linguistic identity.
\end{abstract}

Keywords: Swearing; Gender; Linguistic identity; Sociolinguistics

\section{Introduction}

At one time or another we swear. In almost all languages, swearing is a linguistic device that serves both personal and interpersonal functions. It is for this reason that this linguistic phenomenon deserves the attention of linguists and others interested in language [1]. A swearword is defined as a multifunctional pragmatic unit which assumes, in addition to expression of emotions, various discourse functions [2]. Swearing is the use of a sub-set of a language's lexicon to show strong emotion: it is a function of communication context. It has been observed that the main purpose of swearing is to express emotions [3]. From a sociolinguistics point of view, swearing may be used to identify with friends or age mates and show solidarity, or to isolate people. This is especially in consideration of contextual variables such as the speaker-listener relationship including gender and the social-physical setting [4].

The language of miraa traders has been found to be full of taboo words used to insult. This has been accounted for through politeness theory particularly concerned with face threatening acts. It has been explained that negotiations between miraa traders are characterized by idiosynchratic features such as offensive language with intention to accomplish the social activity of trading compellingly [5]. This paper investigated the social motivations behind swearing in the language of traders, precisely, in a miraa market environment. Such a setting is naturally occurring and it was considered to be very ideal in capturing the social functions of swearing in the speech of traders during their negotiations. The study adopted a corpus-based approach focusing not only on what is produced, but also on why it is produced [4].

\section{Theoretical Approaches to Why People Swear}

Several approaches have been developed attempting to explain why people swear. We explored some of these approaches to make a tentative explanation of the social motivations behind the use of swearwords in the language of miraa traders in the market setting.
According to the Neuro-Psycho-Social (NPS) theory of speech [6], swearing is a socially learned behavior. The theory embraces three aspects of human behavior: neurological control; psychological restraints and social-cultural restrictions. The neurological aspect explains that swearing can be a form of the brain's automatic response to pain, joy, frustration or some other emotion. Swearing can also be done for highly strategic purposes. The psychological aspect considers linguistic competence: a person's use of swearwords, as being determined by their cultural environment together with their personality and religious background. The social-cultural system describes content or appropriateness of a chosen word and considers factors such as speaker power and gender identity. From a NPS perspective, it is likely that miraa traders' linguistic behavior of swearing is socially learned, goal-influenced, and market-contextspecific. In addition, NPS may explain swearing as a function of social variables.

Swearing may also be explained from an approach based on pragmatics [7]. Some of the motives for social swearing listed under this approach include assertion of identity in a group, an intention to shock, amuse, or insult, and marking of social distance or solidarity. Swearing is also influenced by pragmatic variables such as the speakerlistener relationship, the social-physical setting, one's jurisdiction over a location, and the level of formality of the interaction [3]. In this study, we assumed that swearing by miraa traders may serve both intra-individual and inter-individual functions. Aligned with the pragmatic approach, we contend that among miraa traders, swearing is a consciously employed device for group marking, convergence, and differentiation. Swearing serves the above functions in consideration of certain contextual variables such as gender and setting which are very important for successful miraa trading. In developing an analytical framework for this study, we assumed that the approaches are complementary and have clear connections between them. Our emphasis, however, was on the inter-individual functions of swearing.

\section{Categories of swearwords}

Swearwords can be described from various categories. Research has shown that swearwords are sourced from different categories including 
those associated with the following: sex organs; sexual activity; animal names; mental illness including stupidity; religion. Swearword sources may also be a combination of two elements mentioned above [8]. Adding to this observation is the assertion that categories of swearwords can vary widely and "quite often they extend to other aspects of social life" [9]. Nevertheless, research has indicated that the sex domain is the major source of swearwords across cultures [10].

It therefore follows that a discussion of swearing invariably involves the concept of taboo. Taking cognizance of the above argument, this study has adopted both the terms swearwords and taboo words and used them synonymously and interchangeably to refer to swearing with intention to allow semantic consistency.

\section{Swearing and gender}

Gender plays a very significant role in swearing. Though there's a commonly held perception of swearing as a male domain, researchers have identified an increased knowledge and use of swearwords among female respondents $[11,12]$. This has been attributed to the influence of such pragmatic variables as speaker-listener relationship in terms of gender, occupation or status. In addition, swearing among women has been found to increase in frequency due to the social-physical setting of the interaction, whether public or private, by which women make offensive judgments. Nevertheless, research has shown that males swear more than females [13].

The presence of either gender during interactions has been seen to influence swearing behavior. It has been established that females use fewer swearwords in the presence of males while the converse of this is realized in male swearing behavior [14]. While females have increased their usage of swearwords in the presence of fellow females, males have reduced their swearing in the presence of other males. Such patterns imply established in-group/out-group linguistic behavior based on appropriateness judgment. Such judgment is performed with consideration of the gender of interlocutors and the context of interaction [9]. At another level, analyses of actual word usage have shown that use of swearwords related to sexual acts and genitalia is likely with same-sex speakers than mixed-sex speakers. This has been linked to the contextual appropriateness with which both groups view such swearwords usage [9]. Clearly, the gender of interlocutors is a very significant aspect in the analysis of swearing in speech.

\section{Material and Methods}

\section{Research design}

This study was a descriptive survey of language use in a miraa market environment. The study data were qualitative in nature since interest was in capturing the actual swear words used in a miraa market environment.

\section{Participants and procedure}

Participants were drawn from Kĩrĩtirĩ miraa market. It is an open-air market located along Embu-Kivaa road in Mbeere South sub-county, within Embu County. A total of 26 male and female traders were sampled using the social networks approach. They were recorded during their naturally occurring negotiations. The criteria for selection were being a miraa trader as well as a speaker of Kimbeere dialect. Kimbeere is a dialect of Kiembu, a language in the Central Bantu branch family [15]. The dialect is spoken by Ambeere people found within Embu County in the Eastern region of Kenya in East Africa. The region is known for the cultivation of Catha edulis (Khat) as an economic activity. The inhabitants also chew the leaves of the plant as a social custom.

Recording was done while the participants were engaged in buying and selling of miraa after being informed that their speech was being recorded. During recording, a distinction was made between same-sex and mixed-sex negotiations in order to account for the influence of different gender constellations on swearing behavior. A total of 12 recordings involving 2 to 3 participants were obtained and in which 4 recordings involved male only participants, the other 4 had female only participants while the last 4 had mixed-sex participants. An analysis of mixed-sex and same-sex negotiations was deemed a convenient way to have a clearer perception of how swearing serves to construct relations between male and female traders. Table 1 displays the number of recordings, their length, and the distribution of the sample in terms of gender.

\begin{tabular}{|l|l|l|l|l|}
\hline & \multicolumn{2}{|l}{ Length } & \multicolumn{2}{l|}{ Participants } \\
\hline Recording & Minutes & Seconds & Males & Females \\
\hline 1 & 10 & 6 & 2 & 0 \\
\hline 2 & 8 & 40 & 2 & 0 \\
\hline 3 & 12 & 16 & 2 & 0 \\
\hline 4 & 10 & 5 & 2 & 1 \\
\hline 5 & 10 & 29 & 1 & 1 \\
\hline 6 & 10 & 15 & 2 & 0 \\
\hline 7 & 15 & 21 & 1 & 1 \\
\hline 8 & 10 & 16 & 0 & 2 \\
\hline 9 & 10 & 15 & 1 & 2 \\
\hline 10 & 10 & 11 & 0 & 2 \\
\hline 11 & 10 & 26 & 0 & 2 \\
\hline 12 & 10 & 25 & 0 & 2 \\
\hline Sub-Total & 125 & 225 & 13 & 13 \\
\hline Total & 2 hours 9 min & & 26 & \\
\hline & & & & \\
\hline
\end{tabular}

Table 1: Distribution of recordings by gender.

\section{Analysis}

The content of the recorded negotiations was analyzed through a number of steps. First, the recorded negotiations were transcribed on paper. During transcription, the gender of the participants was noted. These transcriptions were carefully studied and the swearwords identified. Secondly, summative analysis was employed where these words were tallied and grouped with regard to their usage in terms of the gender of the speaker. Finally, the recorded transactions were listened to over and over and analyzed using a conversation analysis approach. This determined the motivations for using swearwords during the negotiations. 
Page 3 of 6

\section{Results and Discussion}

The swearwords used in the speech of both male and female traders and their lexical frequencies were as presented in Table 2.

\begin{tabular}{|c|c|c|c|c|c|}
\hline \multicolumn{2}{|c|}{ Swearwords } & \multicolumn{4}{|c|}{ Lexical Frequency } \\
\hline \multirow[b]{2}{*}{ Kimbeere } & \multirow[b]{2}{*}{ English gloss } & \multicolumn{2}{|c|}{$\begin{array}{l}\text { Same-sex } \\
\text { negotiations }\end{array}$} & \multicolumn{2}{|c|}{$\begin{array}{l}\text { Mixed-sex } \\
\text { negotiations }\end{array}$} \\
\hline & & Male & Female & Male & Female \\
\hline Ntheke & Testes & 14 & 0 & 8 & 0 \\
\hline Kagura & Clitoris & 10 & 22 & 15 & 17 \\
\hline Mũthuti & Arse & 5 & 6 & 2 & 2 \\
\hline Mbĩnĩ & Vagina & 15 & 0 & 7 & 2 \\
\hline Mũthinũ & Penis & 9 & 1 & 2 & 2 \\
\hline Kĩvĩcĩ & Uncircumcised male & 17 & 0 & 0 & 5 \\
\hline Kĩrĩgũ & $\begin{array}{l}\text { Uncircumcised } \\
\text { female }\end{array}$ & 0 & 14 & 12 & 2 \\
\hline Nyũkwe & Your mother & 6 & 7 & 6 & 4 \\
\hline Thicwa & Fuck you & 0 & 0 & 18 & 2 \\
\hline $\begin{array}{l}\text { Ngai- } \\
\text { Mwathani }\end{array}$ & God-Almighty & 0 & 2 & 12 & 1 \\
\hline Ngitĩ & Dog/Bitch & 7 & 12 & 1 & 6 \\
\hline Matoko & Genital discharge & 2 & 0 & 8 & 7 \\
\hline
\end{tabular}

Table 2: Kimbeere dialect swearwords and their lexial frequency among male and female traders.

For ease of analysis and presentation, the swearwords in Table 2 were grouped into various categories with regard to where they are sourced: sexuality, religion, bodily discharge, animal names, and social/cultural orientations. Studies have shown that majority of swearwords across cultures contain sexual orientations but taboo subjects can vary widely and quite often extend to other aspects of social life [16]. Table 3 displays the categories into which we grouped the various swearwords.

\begin{tabular}{|l|l|}
\hline Categories & Lexical count \\
\hline Sex organs and body parts & 5 \\
\hline Sexual activity & 1 \\
\hline Animal names & 1 \\
\hline Religion & 1 \\
\hline Bodily discharge & 1 \\
\hline Social/cultural & 3 \\
\hline Total & 12 \\
\hline
\end{tabular}

Table 3: Categories of swearwords.

Table 3 shows that swearwords in the language of miraa traders are drawn from sexuality, religion and animal names. This was consistent with findings that the three are typical sources of swearwords across cultures [17]. In addition, our findings show that sex is the most common source of swearwords in the language of miraa traders. This is well aligned with previous research [5,9]. Apart from these typical sources, swearwords in the language of miraa traders are sourced from other social aspects related to parenthood, and cultural aspects to do with circumcision. Table 4 displays the lexical frequencies of swearwords in all categories by males and females in same-sex and mixed-sex negotiations.

\begin{tabular}{|l|l|l|l|l|l|l|l|}
\hline \multirow{2}{*}{$\begin{array}{l}\text { Swear word } \\
\text { categories }\end{array}$} & \multicolumn{2}{l}{ Male } & \multicolumn{5}{l|}{ Female } \\
\cline { 2 - 8 } $\begin{array}{l}\text { SSN } \\
\text { Sex organs } \\
\text { and body parts }\end{array}$ & 53 & 34 & 87 & & 29 & 23 & 52 \\
\hline Sexual activity & 0 & 18 & 18 & & 0 & 2 & 2 \\
\hline Animal names & 7 & 1 & 8 & & 12 & 6 & 18 \\
\hline Religion & 0 & 12 & 12 & & 2 & 1 & 3 \\
\hline $\begin{array}{l}\text { Bodily } \\
\text { discharge }\end{array}$ & 2 & 8 & 10 & & 0 & 7 & 7 \\
\hline $\begin{array}{l}\text { Social/cultural } \\
\text { orientation }\end{array}$ & 23 & 18 & 41 & & 21 & 11 & 32 \\
\hline Total & 85 & 91 & 176 & 64 & 50 & 114 \\
\hline Note: N = 290. SSN= same-sex negotiations; MSN = mixed-sex negotiations \\
\hline
\end{tabular}

Table 4: Lexical frequencies of swearword categories in same-sex and mixed-sex negotiations.

Results in Table 4 show that males used more swearwords from sex organs and body parts and social/cultural orientation in same-sex negotiations (53 and 23 respectively) than in mixed-sex negotiations (34 and 18 respectively). At the same time, swearwords drawn from sexual activity were used only in mixed-sex negotiations by males and females while no swearword from the same category was used in samesex negotiations. The social-cultural aspect of the NPS theory argues that swearing is a function of content or appropriateness of a chosen word in consideration of factors such as gender identity. The use of swearwords related to sexual activity by both groups only in mixed-sex negotiations indicates the conceptualization of sexual intercourse by both genders was similar and was dictated by culture and social roles of the Mbeere society from which the speech community draws. The findings of our study may also suggest that swearing behavior in the language of male and female traders is dictated by offensive judgments (and contextual appropriateness) with which both groups perceive swearing. Females' offensiveness threshold seems high in the presence of males while that of males is low in the presence of females.

Literature on the pragmatics of swearing explains that such behavior is related to in-group/out-group relationships: women swear more in the presence of other women to reflect an established in-group behavior in which they are reluctant to engage with out-group (male) participants [5]. This implies that female traders felt strongly linked through swearing in a way that made them transact amicably. On the other hand, males increased swearing in the presence of females to perpetuate male dominance. In such a way, males perhaps wanted to dominate females during negotiations in a way that would they would influence the outcome of the negotiation in their favor and therefore buy from females at fairly reduced prices [9]. 
Page 4 of 6

Findings show that females didn't use swearwords from bodily discharge in same-sex negotiations while they tended to use them almost as frequently as males in mixed-sex negotiations. Moreover, the total lexical frequency of swearwords from animal names by females in both types of negotiations is higher (21) than that of males in same category swearwords in both types of negotiations (8). This implied that it was not always that females' swearing was inhibited by the presence of males, and that females used more swearwords than males. From a pragmatics perspective, swearing may be employed as a convergence strategy. This suggests that since swearing is perceived as a male domain, female traders adopted use of swearwords in almost the same frequency as males or a frequency higher perhaps to assert themselves and match or counter male traders' dominance, aggression and competitiveness [9]. They may also have done this to rebel against gender roles [18] and fit into the male dominated miraa trade with desire to score transactional goals. Research on perception of swearing has shown how constant swearing by a speaker leads to violation of expectations on the part of the hearer which triggers arousal. This arousal leads to social evaluations of the swearer by the listener [19] in which case the swearer may be perceived as socially inept [20]. In this case, swearing by both male and female traders may have been influenced by the notion of perception. Among the Ambeere people, taboo language in the speech of women is socially associated with prostitution particularly by men. Therefore, use of fewer swearwords by female traders in mixed-sex negotiations may have been influence by avoidance for such perception. On the other hand, swearing by men makes them positively perceived as aggressive and masculine; qualities that they want to portray especially to women. Again, male traders swearing more in our study may have been dictated by the motive to be perceived as aggressive.

There was low frequency of usage of swearwords from religion in both types of negotiations by women. If the psychological aspect of the NPS theory argues that a person's use of swearwords is determined by their cultural environment which includes their religiosity, it is likely that females used such few swearwords from religion because they are more religious than men [21].

The significance of our findings in this section is that they confirm that swearing is a common linguistic feature in the khat market environment. With khat having been classified as a drug by the World Health Organization [22], growing and/or trading in it will raise moral issues. From both the NPS theory and pragmatics perspectives, swearing in this context may be viewed as a learned and maintained behavior aimed at varied social goals: it is a way in which this speech community intends to rebel against social norms thereby differentiating themselves from other groups in the society. Our findings also confirm that women do indeed swear consistent with previous research on taboo language [10] and contrary to assertions that women are masters of euphemisms [23]. The social-cultural tenet of the NPS theory may be used to explain this phenomenon: swearing by women may be aimed at identifying with the khat traders' culture of swearing and therefore converging with a group that is male dominated. It is a means by which women intended to assert them in order to trade successfully.

\section{Conversation Analysis}

A conversation analysis was done on the recorded transactions with the aim of determining the social aspects of swearing behavior in the language of traders. This analysis was principally grounded on the pragmatic approach to swearing which explains swearing as socially motivated to serve interpersonal functions such as group identity, an intention to insult, and expressing solidarity or marking social distance. Our findings confirm that indeed there were elements of group marking through swearing as well as other social motives as illustrated below. Findings show that swearing was employed with the following intentions:

\section{To deride}

Swearwords were used by traders to mock, scorn and ridicule each other in a harsh way. This was mostly done to achieve both social and transactional goals. Consider;

\section{Recording 11}

$47 \mathrm{~W}$ : Gũkũ tũcanũkĩte mũno tondũ mũndũ mũrũme tocio waku, nĩendia mĩraa, arabu nginamũcuna ngiri! Na nwanakwĩraga ũtige kũthiĩ kũgũrwa! (We have really styled up here because for instance, that husband of yours will sell miraa, and then he'll come to me and I'll take that thousand! And I had warned you not to go get married!).

$48 \mathrm{X}$ : Kwĩna mbia twigitte vandũ! (There's money we (my husband and I) have saved somewhere!).

$49 \mathrm{~W}$ : Ũrakenua na kĩrai kĩgura gĩkĩ nĩkĩo nĩrakwĩra tarĩu ava wĩra waku nĩ manjī! Tarĩu nĩguo ũrĩmîte wirĩte ta ngitĩ! (You're being hoodwinked with this basin (of Khat), and that's why am telling you that your work is for nothing! Look at how you've worked in the farm; you're as black as a bitch!).

$50 \mathrm{X}$ : Kwĩna ngiri thirty $i$ vandũ ndũtige nthiĩ ngoce cio! (There's thirty thousand shillings somewhere, why don't you let me go get it!).

In the above example, $\mathrm{W}$ seems to be mocking $\mathrm{X}$ for having agreed to get married and therefore work in the farms only to be selling khat for her man. W's intentions are clear; to buy khat at reduced prices, and to influence $\mathrm{X}$ in joining her social group.

\section{To degrade miraa}

At the same time, swearwords were used especially while referring to khat to show it as of poor quality or variety, mostly with intention to gain advantage in a transaction. For example;

\section{Recording 2}

64 D: Mũndũ ũũ ongerera mbeca tũtige gũterana mathaa (Increase that money, let's not waste each other's time).

65 C: Ngwĩrire wana mimbia ntheke ndikũmĩüria (I told you I don't want that which makes testes get bloated!).

66 D: Mũndũ ũũ ndwarete mathe mũno kaguraĩ (Swearing) (You are joking a lot).

67 C: Nakwirra ndigũraga mimbia ntheke! (I have told you I don't buy that which makes testes get bloated!).

68 D: Nũkwenda ngũve yo mana? (Do you want me to give it to you for free?).

\section{C: Ndũmbe yo! ( Go ahead!).}

In turn $64, \mathrm{C}$ uses swearwords to imply that D's miraa is of such a poor variety that it should not be consumed. This was perhaps done with C's desire to buy it very cheaply. 


\section{To insult}

Use of swearwords to insult was realized as relatively high among both male and female traders. Research [4,9] has shown that negotiations between khat traders are full of taboo words mostly associated with body parts and which are used to insult. Consider;

\section{Recording 11}

21 W: Rĩrĩa mĩraa írarĩ na mbia-rĩ, rĩrĩa kĩrai kĩraumaga ngiri igĩrĩ-rĩ, araregaga gũkũva nîkĩ? (Why didn't he (your husband) send you (to sell) when khat had good prices, when a basin was going for 2000 shillings!).

\section{X: Ingĩ nĩraũkaga! Ingĩ nĩraũkaga! (But I was coming!).}

$23 \mathrm{~W}$ : Wanawe ũrĩ kĩgura gĩtaku mũno! Nîkĩo nĩmwĩraga mũcanũke! Mũndũ mũrũme arakũva mĩraa ũke ũmwenderie? (You're a very foolish clitoris! That's why I tell you people to style up, how does a man give you khat to come and sell it for him?).

In the above example, W's use of swearwords in turn 23 to insult $\mathrm{X}$ is done strategically. $\mathrm{W}$ wants to portray $\mathrm{X}$ as foolish and perhaps influence the price of khat to come down to her advantage.

\section{To isolate oneself or somebody, or identify with a social group}

Swearwords may be used in instances where there is no anger or frustration. For instance, they may be used to assert our identity in a group. Data from the recorded transactions showed that swearwords were sometimes used by traders to distance themselves or other speakers, or identify with a social group. For example;

\section{Recording 12}

$30 \mathrm{Z}$ : We wambire kũmbĩra ciugo cia kagura-rĩ, ndũmbĩre ngwenderie mirraa! (But you started using swearwords; tell me to sell you khat!).

$31 \mathrm{Y}:$ Tondũ ĩyo nĩ lugha ya thoko! (Because that is the language of the market).

\section{$32 \mathrm{Z:} \tilde{I} \tilde{\imath}($ Okay)}

In this instance, $\mathrm{Z}$ seems to complain at Y's use of swearwords. Z justifies her swearing by claiming swearing is the language used in the khat market. $\mathrm{Z}$ is therefore identifying herself with khat traders at the market through swearing while at the same time seemingly implying that $\mathrm{Y}$ is not in the same social group.

\section{Another instance is exemplified below:}

\section{Recording 2}

52 D: Kavĩcĩ rete mĩraa ĩyo! (You (uncircumcised boy) bring that khat!).

53 C: Kagura mũndũ ũũ ũrambĩta kavĩcĩ? Nĩwĩcĩ nĩ mũthuri we! Urenda kwarangia atĩa? Nĩwĩci nĩnaruire!? (Swearing) (You call me uncircumcised boy? Don't you know am a grown man? What do you want to imply? Don't you know I went through the cut?).

54 D: Ũkĩrua! Waruĩre kũ!? (You circumcised! From where did you do it!?).

\section{C: Naruĩre Kavondorĩ!' (I was circumcised at Kavondorĩ').}

In the above example, $\mathrm{C}$ becomes furious at D's suggestion that he is not circumcised. He quickly protests that he is circumcised, thus identifying himself as a grown man and therefore distancing himself from the uncircumcised people.

Our analysis shows that swearing was a means with which disdain, degradation, and use of insults were exhibited. While these strategies may not be employed anywhere else where Kimbeere speakers engage themselves, they seemed of high value among miraa traders. Precisely, they were a means with which these traders were able to successively accomplish the social activity of trading. Our findings confirm and reinforce our earlier explanation that the social function of swearing is the most prominent in the miraa market setting.

\section{Limitations of the Study}

This study did not consider age of miraa traders as a variable. The age of speakers and that of their listeners have proved to be significant variables in the social context of swearing [5]. From a methodological point of view, use of a structured interview may have introduced different perspectives on swearing behavior. An interview schedule, if carefully formulated, can reveal tacit knowledge that speakers have about why they speak differently in a particular context [5]. Future studies can ascertain whether inclusion of age, as well as an employment of an interview schedule, may reveal different patterns of swearing behavior as well as speaker/listener information on the same.

\section{Conclusion}

This paper aimed at evaluating the social functions that swearing serves in the language of traders in a khat market. Negotiations among miraa traders were recorded and analyzed. The analysis shows that swearing is employed as means of not only achieving varied social goals but also trading compellingly. This study acknowledges swearing in the language of miraa traders as a complex social practice that serves intricate pragmatic functions. It is a means in which these traders are able to first and foremost, socialize, and more significantly achieve highly precious transactional goals of maximizing their profits as well as buying at fairly reduced prices. For female traders, swearing becomes a form of "survival strategy" in a market environment characterized by high competitiveness. Ultimately, swearing is a way in which these traders have come to differentiate themselves from other groups and establish their linguistic identity.

Our study provides support for NPS theory as an appropriate theory in the study of swearing in the language of miraa traders. The fact that the theory draws from various disciplines makes it a strong explanatory framework for swearing among miraa traders as a socially learned goal-influenced linguistic behavior. This study also shows how useful an approach based on pragmatics is in studying swearing among khat traders. Specifically, it has shown how khat traders attend to contextual variables such as speaker-listener relationship and the social-physical setting in the process of swearing.

More research on swearing using the NPS theory of speech is recommended. Continuing research should investigate and explain swearing patterns in other settings for example, formal environments like the workplace. Since there has been too much focus on why, how, and when people swear in informal contexts-and as a result the assumption that swearing is a linguistic device that is employed only in informal contexts-an investigation of swearing patterns in formal contexts can expose different swearing behavior. Further, this can be an opportunity to evaluate more participant variables. 
Citation: $\quad$ Mukuni DM, Ireri AM, Nthiga PM, Owili FA (2016) The Social Function of Swearing in a Miraa Market Environment. Arts Social Sci J 7:

Page 6 of 6

\section{References}

1. Jay T (1992) Cursing in America. John Benjamins, Philadelphia.

2. Drescher M (2000) Tabarnouche Eh! is C'etiat-For a communicative approach jorunen Francois Quebecois. Papers praxematique 34: 133-160.

3. Jay T, Janschewitz K (2008) The pragmatics of swearing. Journal of Politeness Research 4: 267-288.

4. Fagersten KB (2012) Who's swearing now? The social aspects of conversational swearing. Cambridge Scholars Publishing, United Kingdom.

5. Miriti G (2012) Politeness and speech accomodation in intercultural business negotiations: A case of Igembe and Somali miraa traders. Kenyatta University, Kenya.

6. Jay T (2000) Why We Curse: A Neuro-psycho-social theory of speech John Benjamins Publishing Company, Philadelphia.

7. Crystal D (1995) The Cambridge encyclopedia of English language Cambridge University Press, Cambridge.

8. Ariani D (2002) The use of swearwords among people in a bus terminal Indonesia University of Education, Indonesia.

9. Mukuni D (2015) A Psycho-Social analysis of common Kimbeere swearwords in the language of traders in Kĩrĩtirĩ miraa market, Embu County. Kenyatta University, Kenya.

10. Shoemaker W (2000) Dirty words and the offense principle. Law and Philosophy 19: 545-584.

11. De Klerk V (1992) How are taboo words for girls? Language in Society 2: 277-289.

12. Sutton A (1995) Bithes and skanky hobags: The place of women in contemporary slang. In: Hall K, Bucholtz M, (eds.) Gender Articulated: Language and the socially constructed self. Routledge, New York.
13. Berger C (2003) The myth of gender-specific swearing. Verlag fur Wissenchaft und Forschung, Berlin.

14. Gomm I (1987) A study of the inferior image of the female use of the English language as compared to that of the male. Edge Hill College, Ormskirk.

15. Guthrie M (1967) The classification of Bantu languages. Dawsons of Pall Mall, London.

16. Wardhaugh $\mathrm{R}$ (2006) An introduction to sociolinguistics (5th edn.) Blackwell.

17. Andersson LG, Hirsch R (1985) A project on swearing: A comparison between American and Swedish. In: Swearing report no. 1, Dept of linguistics at the University of Gutenberg, Gotenborg.

18. Stapleton K (2003) Gender and swearing: a community practice. Women and Language 26: 22-23.

19. Johnson DI, Lewis N (2010) Perceptions of swearing in the work setting: An expectancy violations theory perspective. Communications Reports 26: 106-118.

20. Winters AM, Duck S (2001) You ${ }^{* * * * !: ~ S w e a r i n g ~ a s ~ a n ~ a v e r s i v e ~ a n d ~ a ~}$ relational activity. In: Kowalski RL (ed.), Behaving badly: aversive behaviors in interpersonal relationships. American Psychological Association, Washington DC pp: 59-77.

21. Freud S (1953) Three essays on the theory of sexuality. Hogart Press, London.

22. World Health Organization Expert Committee on Drug Dependence: Thirty-fourth report-2006. WHO report series 942.

23. Lakoff R (1975) Language and woman's place. Harper and Row, New York. 